\title{
Thirty days in Sierra Leone
}

\author{
Brooks, $\mathrm{JI}^{1,2^{*}}$ \\ ${ }^{1}$ National Microbiology Laboratory, Public Health Agency of Canada, Winnipeg, MB \\ ${ }^{2}$ Centre for Immunizations and Respiratory Infectious Diseases, Public Health Agency of Canada, Ottawa, ON \\ *Correspondence:James.Brooks@phac-aspc.gc.ca
}

It was September 29, 2014. On that day, 6500 cases of Ebola with 3500 deaths had been reported in West Africa; the first patient with Ebola in the United States had been admitted to hospital and was about to transmit the virus to two nurses. Ebola was sweeping through West Africa and knocking on North America's door. I was running one of the Public Health Agency of Canada's (PHAC) National HIV Laboratories and the boss walked into my office and said: "Brooks, if you want to make a contribution to public health, now is your time." Fifteen minutes later, via a teleconference, I had volunteered to perform Ebola diagnostics at one of PHAC's National Microbiology Laboratories (NML) Mobile Field Laboratories in Sierra Leone.

As an infectious diseases physician, my interests had always been in emerging infections and this Ebola outbreak was my chance. My wife and family knew my passion and urged me to go. Within a few short days, I had received the green light from my Director, rearranged my clinics, organized coverage for my patients, handed off my files and flew to Winnipeg for lab training. People at the NML took time out of their busy schedules to provide me with the training that would ensure I had the skills I needed. The NML Operations Center fully outfitted me with everything I would need to keep me going in the jungle. Occupational health fit tested me for my respirator and medical staff provided me with a first aid kit, bed net, mosquito repellant and a bucket of antibiotics. I felt like James Bond being given an assignment; these guys knew what they were doing. Then, I was sent back to Ottawa to be medically cleared for deployment and happily received a generous number of vaccinations.

Due to the fluidity of the epidemic and the changing requirements/availability of personnel, the deployment business, like the army, has the familiar "hurry up and wait" tempo. As the uncertainty and anxiety increased, I started to think that maybe I would not deploy at all. So I let some people know that it was likely that I would go, but I didn't want to tell everyone in case it just didn't work out. Nevertheless, the word did get out and I was moved by how many of my friends and colleagues came up to quietly say thank-you for helping, or that they were proud of me. Others offered to drive my kids to hockey practices or take them to tournaments. I received emails from friends who knew that my wife would be too proud to ask for help but pleaded with me to ask them to help if needed. Finally, on December 15, the veil of uncertainty was lifted: I received a message along with three other colleagues that we would be heading to West Africa on December 30th. The travel group at the NML had our tickets ready to go; all we had to do was show up at the airport.

On December 31, 2014, after a 36 hour journey I found myself stepping out onto the tarmac into the sticky heat of Lungi International Airport in Freetown, Sierra Leone. The plane had been full of ex-pats from different NGOs who were all coming to help out. As I entered the terminal I received the Ebola baptism through washing my hands in bleach; a ritual that I was to repeat 10,000 times over the next 30 days. Looking around, I saw that everyone looked sweaty. Was it the heat or did they have Ebola? I wondered. Someone brushed up against me. Whoa! I jumped back. Sierra Leone is strictly a "no touch" zone. What if they had Ebola? I think, "Oh no, I have only been here five minutes and I now have Ebola." I pulled out my small bottle of Purell. It felt good on my hands like a soothing, invisible shield. Then I began my mantra: "Hand over the passport, Purell, reach for my luggage, Purell, count the millions of Leones from the currency exchange, Purell, Purell, Purell."

Stepping out into the hazy night, I saw and smelled the smoke of perpetual fires from bush clearing and burning waste. I was then immediately surrounded by men wanting to help me with my luggage. I crossed an unpaved parking lot and searched frantically in the darkness for anybody from Médecins Sans Frontières (MSF), the organization that was to host me for the next 30 days. The men who offered to help with my luggage then wanted money, along with two of their friends who appeared out of the darkness. "Do they have Ebola?" I wondered. I took out my Purell. Amidst the swirling chaos of heat, smoke, sweat and shouting that ensued, the MSF driver appeared and took my bag which immediately disappeared. A luggage receipt was pressed into my hand that miraculously reunited me with my bag in Freetown. Purell. Pulling out of the parking lot, in a minibus that would 
take me to the Sea Ferry, the face of one of the men who "helped" with my bag pressed up against the window and then faded into the night. Welcome to Freetown.

Before I made it to a thoroughly modern hotel that was to serve as the nexus for both my outbound and return journeys, I had to take the Sea Ferry across the Sierra Leone River to Freetown. The minibus traveled to the ferry terminal on a road that I naively thought was the roughest road imaginable. Someone called my ticket number and I walked along a $100 \mathrm{~m}$ dock into the inky blackness where the river and the sky had become one. An open boat, with seats for 20 loomed out of the darkness. I was provided with a lifejacket with a broken zipper that had the feel, and likely the buoyancy, of a lightweight down jacket. Two 250hp Mercury outboards sprang to life and then hurled us forward into nothingness. In the distance, the only thing that I could see was an enormous forest fire burning on the distant shore. The ride on the ferry was a pivotal experience for me. Things were so completely beyond my control, in a way that any over-riding structure in which I would normally give up this control did not exist. At this point, I realized that to move forward, to be able to perform in my job and to be happy, I needed to give myself over to Sierra Leone. That decision made all of the difference.

At 0600 the next day, my three colleagues and I, and all of the equipment needed to resupply two laboratories, were loaded into a Toyota Land Cruiser. Now this was no 5-star African safari. These Land Cruisers are built to MSF specifications. That means there are no electronics, no ABS, no rear-defroster, no $A / C$, the tires have tubes, you sit sideways on hard benches, and there is no turbo on this diesel. But we were lucky, our driver owned a cowboy hat and soon we found ourselves rolling into the jungle listening to real hurtin', country music. Over the next nine hours we traveled $300 \mathrm{~km}$ from the Western to the Eastern edge of the country on roads that changed from paved, to gravel, to dirt, to "are you sure that this is a road?" During that epic journey, our aching butts and all our gear were transferred into five consecutive vehicles until our last vehicle, Bravo (B)-4 rolled up to "Kilo Base" - the Luawa Hotel Resort in Kailahun. Stepping out into the scorching 35 degree heat, someone took my temperature, I again washed my hands in bleach, presented the soles of my shoes for bleach spray before saying hello to my home for the next 30 days.

I waded through the heat, grabbed a drink and headed over to the dining area to meet some of my new MSF colleagues. Not only were the members of MSF courageous, having been on missions in Somalia and South Sudan, their skill sets were off the charts. Need a Tour de France bicycle mechanic? No problem, go talk to the guy who organizes the logistics on the base. Oh, were you thinking of holding a concert? Easy, go to the Ebola Management Centre (EMC) and ask the nurse from Ottawa who is also a concert violinist. And do you have a boat that needs to be sailed from the Caribbean to Europe? Ask the guy in charge of water sanitation. When he is not racing yachts around the world, or riding his motorcycle across Africa, he could take that sailing trip for you solo. Chemical, biological, nuclear incidents? Trauma management? We had a Dutch doctor/nurse combination that could look after all of those. I had washed my hands in bleach again and sat down with this very talented group for my first of 30 consecutive chicken and rice dinners. After that I took the first of 30 cold showers, and only then did I crawl under my mosquito net and went to sleep. Tomorrow was a work day!

The following morning, I grabbed my malarone, a multivitamin and my all-important Purell, before heading out with my colleagues to the EMC for a hand-over briefing from the team that had been manning the Mobile Lab since December 1st. The four of us had jumped into the Land Cruiser and the driver called the radio room "Kilo Base. Kilo Base. This is Bravo-4. I have 4 Echo's (Ex-pats) on board. Heading to the EMC (Ebola Management Centre). Over." The steel gates of Kilo Base swing open and we ventured out into the half-light of dawn.

The first of my daily journeys began with a ride through semi-rural pastoral beauty populated only by sleeping dogs and the occasional ghostly midnight traveller who balanced their belongings carefully on their heads. We then passed through the small town of Kailahun which is the commercial and bureaucratic center of the district serving as the first port of call for goods travelling from Guinea. In the breaking dawn I could see half-destroyed buildings and burned out houses left standing as if to testify against the violence of the civil war that ended more than a decade earlier in 2002. The truck passed faded civic signs of national pride proclaiming the rebirth of Sierra Leone with slogans preaching cooperation and healing. We passed the mosque, adjacent to the evangelical church and, as we drove up another hill, the road was split in two by a trench formed during the rainy season that was now a month gone. The town began to stir; I saw people brushing their teeth beside the road, mothers cooking breakfast on an open fire, and pockets of little kids screaming "Poomway" (white person) and waving madly; hoping to get a wave in return. The B-4 lurched and groaned as it climbed one more hill and before we made a left turn and I caught my first sight of the EMC in the distance, literally, carved out of the jungle. 
As we stepped out of the brilliant African sunlight into the darkened semi-permanent structure of the change rooms, the bleach cleansing and temperature taking rituals were repeated. Disoriented among the crush of people, I was told to ask for greens and white rubber boots - the battle dress of Ebola fighters. The clerk handed me clothing that fit me like a set of Lulu's but I was too embarrassed to ask for different ones so I immodestly stepped out of the change room. I hobbled along the rock-strewn no-man's land between the high risk (Ebola patients) and the low risk zones where the lab was located, wearing one boot that was too big and one that was painfully too small. As I walked past rows of enormous canvas tents draped with sun shades or extended with corrugated iron roofs friendly staff called out "Bee-ay-ee!" or "How did you sleep?" I didn't know how to respond, so I smiled a bewildered smile and headed to the mildewed lab tents at the far end of the EMC.

When I arrived, I opened the flaps of the first tent and entered. I saw a few familiar instruments and a freezer but when I saw the isolation tent where we opened Ebola specimens, that was where the familiarity came to an end. All the equipment was laid out on rough-hewn wood-tables that sat on a well-worn tarp covered in the ubiquitous red dirt. This did not look like any lab that I had worked in before.

Giving myself to Sierra Leone meant changing my perspective on so many levels. In Ottawa, I had spent hours carefully crafting laboratory guidelines for safely handling possible Ebola specimens under the most stringent conditions possible. Outside my new lab, staring at me from three feet away, were three white polyethylene buckets sitting in the red gravel of the EMC full of potential Ebola specimens. As I struggled to reconcile these vastly different environments, I nearly fainted as a member of the departing team sprayed a lid down with bleach and opened the container to count the number of specimens inside. I nervously pulled out my Purell, took three steps backward and looked down at my colleague who, to my amazement, was still alive and staring back at me. He asked, "Well are you going to test these specimens or what?" I grabbed my well-thumbed protocol that I had carefully annotated while training at the NML and re-read eight times on the flight down and thought: "Where do I start?" I nervously looked around to buy time and saw a giant pump bottle of Purell in the lab. I took five long pulls. It felt good as I rubbed it on my hands and I felt my courage returning. I took a breath and decided that a good place to start was "Step 1."

I had a great lab partner, Qiu, with whom I shared lab duties. She was a bit of a hot-shot, as she had developed ZMapp, the monoclonal antibodies which are probably the most effective Ebola treatment on the planet. She handled the tough stuff, wearing the full personal protective equipment and neutralizing the "hot" specimens before handing them off to me but nonetheless, I was critical to the operation. I got the satellite connection to the internet running in the morning, then hooked up the router to the PCR machines, and removed insects, lizards and rats from the tent. I reminded her that I was not completely useless. My other duties included purifying the viral RNA from the neutralized specimens and then running the Ebola testing. But this point should be made absolutely clear: I was just a guy who had a passport, a lot of support and lab experience. The real magic came from the people in the Special Pathogens Laboratory at the NML who developed the tests and worked in the mobile labs for most of the Ebola outbreaks that had occurred in Africa.

Over the next month, in two tents in the middle of the jungle, with intermittent diesel generator-supplied power, we ran hundreds of Ebola tests without a single failure. After working in an NML diagnostic laboratory it was amazing to see this field lab providing results that were every bit as robust and reliable as those that could be obtained in those spotless facilities back home. On our first day we tested for Ebola, as well as for Malaria and Lassa fever. This day we found no Ebola, only malaria. With the laboratory work complete and the equipment decontaminated, I reported the results to the EMC medical team, changed out of my tight clothing, got bleached again and climbed back into the Land Cruiser for the return to Kilo Base.

After 30 straight days of the same meals, the same trips, the same tight clothes, the same laboratory testing, it all came to an end. Qiu had moved on to another field lab and I was left alone at the EMC. As the sun set, I watched the smoke drift away from the burning of the now vacant tents in the high risk zone. As the last man standing, in an EMC devoid of Ebola cases, I looked around and knew that my work was done. I packed up the lab, loaded the equipment into a pick-up truck, Purelled my hands, climbed into the B-4, and listened for the last time to the driver who made his radio call: "Kilo Base, Kilo Base. I have one Echo on board. Coming to your location." I was going home.

My bags were loaded in the back of B-4 as I waited at Kilo Base. I heard the thump-thump-thump of the helicopter growing louder, my cue to run to B-4 for the ride to the soccer stadium where I would meet the UN helicopter that would take me to Freetown. As the helicopter lifted off, waving children scattered like leaves in the wind, and I began to reflect on my experience. I thought about the relationships built with the national staff and their efforts to 
teach me the local Mende language. I marveled at the synergy that existed between the NML's mobile laboratory and MSF. The reputation of MSF gave us the freedom to work safely and effectively in Sierra Leone. The organization has been superbly managed and has made a tremendous contribution to the West African Ebola epidemic through their early and courageous assistance. However, MSF did not have a lab to test patients for Ebola or, when patients survived, to determine whether they could be safely discharged to their families. The mobile lab provided this diagnostic piece that allowed the EMC to function. Although I did not see any Ebola cases during my 30 days in Sierra Leone, the 450 bodies lying in the graveyard beside the EMC silently testified that Ebola had been there. During the six months the field lab had been operating, more than 2700 tests had been performed on 1200 admissions. In total, twenty-one remarkable PHAC employees travelled to Sierra Leone to staff the mobile laboratories in Kailahun and Magburaka, with every one making an enormous contribution on behalf of Canada. 